\section{Sodium Benzoate}

Through the last decade of scientific research, there has been a gradual focus shift from monoamines as the main therapeutic target of psychopharmacology. Nowadays it's the glutamate system, especially its receptors, that has become increasingly interesting in terms of possible treatment modalities. In fact, altered functioning of N-methyl-Daspartate (NMDA) subtype of glutamate receptors in the brain has an important role in the pathophysiology of schizophrenia. We must stress that NMDA receptors are proven to have a critical role in synaptic plasticity, neurocognition and neurotoxicity. Based on these findings, improved signalisation via NMDA receptors in the brain is considered to be a new therapeutic approach in alleviating symptoms of schizophrenia [1]. One of the methods for improving NMDA receptors function is increasing the level of $\mathrm{D}$-amino acids by reducing their metabolism. This can be achieved with an D-amino oxidase inhibitor. D-amino oxidase is a flavoenzyme which breaks down D-amino acids by oxidative deamination. Recent genetic research has identified a mutation on chromosome 13 in patients with schizophrenia that codes two proteins (G30 and G72) associated with D-amino oxidase, with increased expression and activity in post-mortem brain samples of patients with schizophrenia compared to healthy population $[2,3]$. D-serine, one of the amino acids regulated with $\mathrm{D}$-amino oxidase is a potent endogenous coagonist of NMDA receptors and it has been proven that $\mathrm{D}$-amino oxidase inhibitors increase the concentration of D-serine in the blood and brain [2].

As the first molecule from this group we present sodium benzoate (Benzoate - SyneuRx, Clozaben, NaBen, SND 51, SND-11, SND-12, SND-13, SND-14), which is currently in the clinical research phase as addon therapy in treatment of schizophrenia in adults $[4,5]$. Benzoic acid was discovered in the 16th Century by dry distillation of gum benzoin, first described by Nostradamus. In nature it appears in free form and in the form of benzoic acid esters in many plants and animals. It is also present in various types of food, including dairy products. Benzoic acid salts are known and safe food preservatives widely used in industry, especially in meat processing [6]. It has been clinically demonstrated that sodium benzoate improves a broad spectrum of symptom domains in schizophrenia and is clinically signif- 
icant for patients with chronically expressed symptomatology [4]. It is very promising to see that this molecule alleviates symptoms of schizophrenia that had resisted therapy with antipsychotics. This indicates a potential effectiveness in therapy resistant cases. It is important to stress that sodium benzoate as an „NMDA enhancer” also acts on cognitive symptoms of schizophrenia, which is especially important as cognitive symptoms are considered to be the key problem and a significant predictor of outcome in schizophrenia [6]. Sodium benzoate (under protected name $\mathrm{NaBen}$ ) has been named an ,orphan drug" by the American Food and Drugs Administration (FDA) i. e. suitable for paediatric patients with schizophrenia and in cases of clozapine treatment refractory schizophrenia. The same agency considers this molecule as breakthrough therapy, thus attempting to encourage and speed up drug development for treatment of schizophrenia in adults. A $\mathrm{IIb} / \mathrm{III}$ phase of a multicentric prospective double blind, placebo controlled research study on the safety and efficiency of $\mathrm{NaBen}$ as additional therapy of adult patients with schizophrenia, is currently being conducted. The time of its market release is unknown. $[6,7]$. The chemical structure of sodium benzoate is presented in figure 1.

Assistant Professor Vjekoslav Peitl, MD, PbD

Deputy Editor

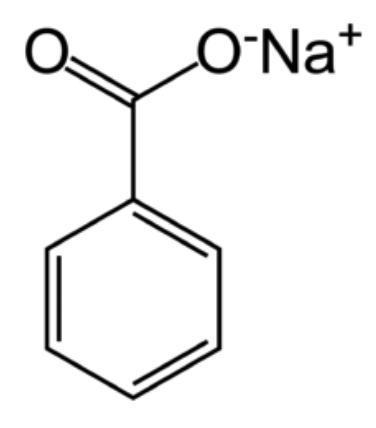

Figure 1. Chemical structure of sodium benzoate

\section{References}

1. Stahl SM. Stahlovi temelji psihofarmakologije. Jastrebarsko: Naklada Slap; 2017.

2. Smith SM, Uslaner JM, Hutson PH. The Therapeutic Potential of D-Amino Acid Oxidase (DAAO) Inhibitors. Open Med Chem J. 2010;4:3-9.

3. Karlović D, Peitl V, Silić A. Shizofrenije. Jastrebarsko: Naklada Slap; 2019.
4. Lin $\mathrm{CH}$, Lin $\mathrm{CH}$, Chang YC, Huang YJ, Chen PW, Yang HT, Lane HY. Sodium Benzoate, a D-Amino Acid Oxidase Inhibitor, Added to Clozapine for the Treatment of Schizophrenia: A Randomized, Double-Blind, Placebo-Controlled Trial. Biol Psychiatry. 2018;84:422-32.

5. Adis Insight. Sodium benzoate - SyneuRx [Internet]. Springer Nature Switzerland AG. 2019 [cited 
April 26th 2019]. Available from: https://adisinsight.springer.com/drugs/800041499

6. Lane HY, Lin CH, Green MF et al. Add-on Treatment of Benzoate for Schizophrenia. JAMA Psychiatry. 2013;70:1267-75.
7. World Health Organization. International Clinical Trials Registry Platform [Internet]. WHO. 2019 [cited April 26th 2019]. Available from: http://apps.who.int/trialsearch/Trial3. aspx?trialid $=$ NCT02261519 